ISSN: 1679-3013

D.O.I.: 10.5914/1679-3013.0071

\title{
FIELD STUDY OF A SIMULATED SUBSURFACE GAS BLOWOUT IN TROPICAL AND SHALLOW WATER ALONG THE BRAZILIAN COAST
}

\author{
Fabiana S. LEITE ${ }^{1,2, *}$ \\ Moacyr ARAUJO ${ }^{1,2}$ \\ Marcus A. SILVA ${ }^{1,2}$ \\ Rodolfo A. SILVA ${ }^{1,2}$ \\ Pedro TYAQUICA ${ }^{2}$ \\ Enrique L. DROGUETT ${ }^{2}$
}

Recebido em: 20/05/2012

Aceito em: 03/09/2012

Although oil and gas exploration from the sea floor has experimented a rapid grow in the low latitude regions, very few gas blowout experiment in tropical and shallow waters has been published by the scientific community. This study aims to increase the knowledge concerning the gas behavior during a subsurface blowout in tropical shallow seawater. Field experiments were carried out by simulating a subsurface blowout with natural gas at approximately $30 \mathrm{~m}$ depth off Suape harbor, in the Northeast Brazilian coast. Four distinct scenarios with varied conditions of geophysical forcing were associated with different fluxes and seasonal periods. The methane fluxes released during the scenarios were set to 3,000 and 9,000 L.h ${ }^{-1}$ (low and high flows, respectively). During the austral summer were registered east-northeasterly winds with mean intensity of $7.2 \mathrm{~m} . \mathrm{s}^{-1}$. Significant wave heights were around $0.9 \mathrm{~m}$ propagating westward. Surface current intensities around $0.5 \mathrm{~m} . \mathrm{s}^{-1}$ with south-southwest direction; vertical stratification; gas plume displacement were registered toward south-southwest and plume width up to $2.7 \mathrm{~m}$ close to the surface. During the austral winter were observed winds blowing from the southeast with mean intensity of $6.6 \mathrm{~m} . \mathrm{s}^{-1}$. Significant wave heights were around 1.6 $\mathrm{m}$ propagating northwestward. Similar summer current intensities were toward the northeast. A slight mixed water column was registered. Gas plume width was higher than $1.3 \mathrm{~m}$ close to the surface and presented a northeast-northward displacement. The gas plume movement was always influenced by the tidal and meteorological forcings, in that order. Difference in the plume width occurred mainly in the upper surface layer and current measurements indicated that the gas bubbles do not affect the local hydrodynamics.

Key words: Experimental data, Natural gas, Underwater blowout, Tropical Atlantic.

\section{RESUMO}

Apesar da exploração marinha de óleo e gás ter experimentado um rápido crescimento em regiões de baixa latitude, poucos experimentos em águas rasas tropicais têm sido publicados pela comunidade científica. Este estudo foi desenvolvido com o objetivo de incrementar o conhecimento acerca do comportamento de uma pluma de gás natural durante um vazamento acidental em águas rasas tropicais. Experimentos de campo foram realizados através da reprodução in situ de um vazamento de gás natural a aproximadamente $30 \mathrm{~m}$ de profundidade ao largo do Porto de Suape, na costa nordeste do Brasil. Quatro cenários distintos foram associados a diferentes fluxos de gás e períodos sazonais. Os fluxos de gás liberados durante os cenários foram configurados

1. Laboratory of Physical and Coastal Oceanography at the Oceanography Department (LOFEC/DOCEAN), Federal University of Pernambuco, Av. Arquitetura, s/n, Cidade Universitária, 50740-550, Recife - PE, Brazil.

2. Center for Risk Analysis and Environmental Modeling (CEERMA), Federal University of Pernambuco, Av. Arquitetura, s/n, Cidade Universitária, 50740-550, Recife - PE, Brazil. E-mails: fasoaresl@yahoo.ca; moa@ufpe.br; marcus@ufpe.br; rodolfoas@hotmail.com; ealopez@uol.com.br. 
LEITE, F. S. et al. Field study of a simulated subsurface gas blowout in tropical and shallow water along the Brazilian Coast.

para 3.000 e 9.000 L.h ${ }^{-1}$ (vazões baixa e alta, respectivamente). Durante o verão austral foram registrados ventos de leste-nordeste com intensidade média de 7,2 m.s ${ }^{-1}$; altura significativa das ondas por volta de 0,9 m propagando-se para oeste; intensidade de corrente na superfície de aproximadamente $0,5 \mathrm{~m} \cdot \mathrm{s}^{-1}$ com direção sul-sudoeste; estratificação vertical; deslocamento das plumas na direção sul-sudoeste e largura das plumas de até $2,7 \mathrm{~m}$ perto da superfície. Durante o inverno austral foram observados ventos de sudeste com intensidade média de $6,6 \mathrm{~m} \cdot \mathrm{s}^{-1}$; altura significativa das ondas por volta de 1,6 $\mathrm{m}$ propagando-se para noroeste; intensidades de corrente superficiais similares às do verão direcionando-se para nordeste; uma coluna d'água levemente misturada; plumas de gás com largura maior do que $1,3 \mathrm{~m}$ próximo à superfície e deslocamento para nordeste-norte. O movimento das plumas foi influenciado pelas forçantes de maré e meteorológica, nesta ordem. A diferença no diâmetro da pluma ocorreu principalmente na camada mais próxima à superfície. As medições de correntes indicaram que as bolhas de gás não afetam a hidrodinâmica local.

Palavras chave: Dados experimentais, Gás natural, Vazamentos submarinos, Atlântico tropical.

\section{INTRODUCTION}

Oil and gas exploration and exploitation from the sea floor has been a growing and lucrative activity around the world. With this growth, the possibility of an accidental oil/gas release increases and consequently rises the need for a better understanding of the evolution (and dimensions) of oil/gas plumes in seawater. More specifically, it is important to know where, when and how much gas will reach the surface. This motivation requires realistic descriptions of blowout scenarios through in situ experiments. Furthermore, as a part of contingency planning, these experiments would provide baseline data for the calibration and validation of computational models developed to describe subsurface plume behavior (e.g., RYE et al., 1997; YAPA et al., 1999; CHEN and YAPA, 2002; JOHANSEN et al., 2003).

Gas expands as it rises along water depth because of the pressure decrease and thus increases the buoyancy of the jet/plume (ZHENG et al., 2002). There are many differences between deep and shallow water blowouts (ZHENG et al., 2002). In deep water blowouts the gas hydrate formation and decomposition occur due to the high pressure and low temperature, as well as gas dissolution when the water layer is deep. For blowouts at shallow to moderate depths, the gas dissolution from rising bubbles into seawater may be negligible and no hydrates are observed (JOHANSEN, 2000).

In situ natural gas releasing experiments are expensive and demand logistical planning because they require manpower, equipment and vessels. Furthermore, these experiments are dangerous because methane gas clouds can generate explosions (FISCHER, 1982; JOHANSEN et al., 2003; BEEGLE-KRAUSE and LYNCH, 2005). The major concerns from accidental gas and oil blowouts are not only explosion/fire (CHEN and YAPA, 2002). Other factors include the toxicity risks to humans and to the environment, and the commitment of ship buoyancy due to the density decrease caused by the oil/gas mixture. As a consequence very few in situ experiments have been reported in the literature, and most of them have been carried out in high latitude/deep water situations (BREWER et al., 1997; RYE et al., 1997; JOHANSEN et al., 2003).

Brewer et al. (1997, 1998), for example, investigated the process of methane hydrate formation in experiments conducted during January 1996 at the depth of $910 \mathrm{~m}$ in Monterey Bay, USA. The authors supplied a remotely operated vehicle (ROV) with a methane gas tank, two types of sediment and four samplers, while ambient seawater pressure and temperature were registered. They concluded that the formation of hydrates is rapid in seawater and that the sediment type is important for the hydrate formation pattern. Rye et al. (1997) performed an in situ experiment with air and oil subsurface release at $106 \mathrm{~m}$ during June 1996 in the North Sea. They reproduced different blowout conditions and monitored the plume and the resulting surface oil slick. Remote sensing of the surface slick was obtained, and Metocean buoys, CTD 
LEITE, F. S. et al. Field study of a simulated subsurface gas blowout in tropical and shallow water along the Brazilian Coast.

(conductivity, temperature, depth) and ROV were used. Measurements were applied for improving blowout models. The authors observed that the sampling methodology was appropriated and that the model showed good agreement with sea observations. Real and modeled plume presented the same proportions, although the size of the slick at the sea surface was overestimated by the model.

The experiment performed by Bulatov et al. (2002) was based on gas plume detection by microwave remote sensing methods without attention to the physical conditions of the plume. The experiment was executed during 2000/2001 using compressed air in the Black Sea. The authors observed that radar images of the perturbed zone presented great polarization dependence and concluded that microwave remote sensing is effective for detecting underwater gas pipe leakage.

The DeepSpill set of experiments were also carried out by Johansen et al. (2001, 2003) during June 2000 at a depth of $844 \mathrm{~m}$ in the Norwegian Sea. The main goals of these experiments were to obtain high-quality data from a deep water oil/gas release and to use them to calibrate deep water plume models (CHEN and YAPA, 2002). They also intended to explore alternative methods to track the oil plume. For the trials, the authors used ROVs, echo sounders, an ADCP (acoustic Doppler current profiler), a CTD and a rosette, in addition to boats, vessels and airplanes. The results indicated that the gas had dissolved entirely by $150 \mathrm{~m}$ beneath the surface, and no gas hydrates were formed. Furthermore, the oil reached the surface a few hundred meters from the blowout source about one hour after the initial release.

In this paper we present a comprehensive data set of geophysical and gas release measurements obtained from in situ experiment carried out off Northeast of Brazil. These measurements are expected to enhance the knowledge concerning gas blowouts in shallow tropical waters, supplying baseline data for blowout model calibration and validation. Hydrological and hydrodynamic data were collected during distinct seafloor gas plume releases at approximately $30 \mathrm{~m}$ depth. Measurements were conducted during neap/spring tides of summer/dry and winter/rainy periods. It was expected that the gas plume would quickly rise to the surface following the local hydrodynamics and that gas entrainment would be the major process acting on the plume evolution. The paper is structured as follows: a detailed description of the experimental set-up is provided in the Material and Methods Section; the measurements obtained during the experiments are described in the Results and Discussion Section. Finally, the primary conclusions and recommendations are presented in the Conclusion Section.

\section{MATERIAL AND METHODS}

\section{Study Area, Planning and Preparations}

The field work is comprised of in situ observation of a natural gas plume throughout the water column in the coastal region near the Suape Harbor industrial park area, Pernambuco, Brazil. According to the Köppen-Geiger climate classification scheme (PEEL et al., 2007), the climate is warm and humid (type Am) in the region. Two well-defined seasons are observed, which are the dry season (from September to March) and the rainy season (from April to August). The average annual rainfall is $1,500 \mathrm{~mm}$, and the evaporation is $1,200 \mathrm{~mm}$. According to Araujo et al. (2005), semidiurnal tides occur at Suape with a mean spring (neap) range of $2.2 \mathrm{~m}(1.1 \mathrm{~m})$. The southeasterly trade winds are predominant throughout the year, oscillating from the east and the northeast during summer (LINS, 2002).

A weak thermocline (halocline) occurs near the surface as a result of solar radiation (evaporation) during the day. Below this region, a well-mixed and homogeneous flow has been observed. The current intensity indicates the influence of momentum exchange near the surface and bottom boundary layers (ARAUJO et al., 2005). According to the upper flow structures, the authors observed strong surface variations in the current intensity and direction, which were associated with slack waters, when the wind effects were more pronounced. The authors also noticed weak wind shear effects near the surface that were associated with strong bottom variations in current direction during the 
dynamic tidal stages, when gravitational forces drive the flow. As stated by Araujo et al. (2005), the energy balance is often driven by the equilibrium between the production and dissipation of turbulent kinetic energy (TKE) near boundaries. The stronger dissipation rates are associated with the surface and bottom boundary layers during spring tides, and the less accentuated rates occur at inner regions of the flow. The regions of maximum TKE production and vertical diffusion are associated with different levels of maximum energy.

The experiments were planned as two-day campaigns. The site for the experiments was determined considering the maximum depth that could provide good visibility in the water column, logistic viability and security. Following this criterion, an area of 30 meters depth was defined that is approximately $11 \mathrm{~km}$ from the coastline of Cabo de Santo Agostinho (Fig.1).

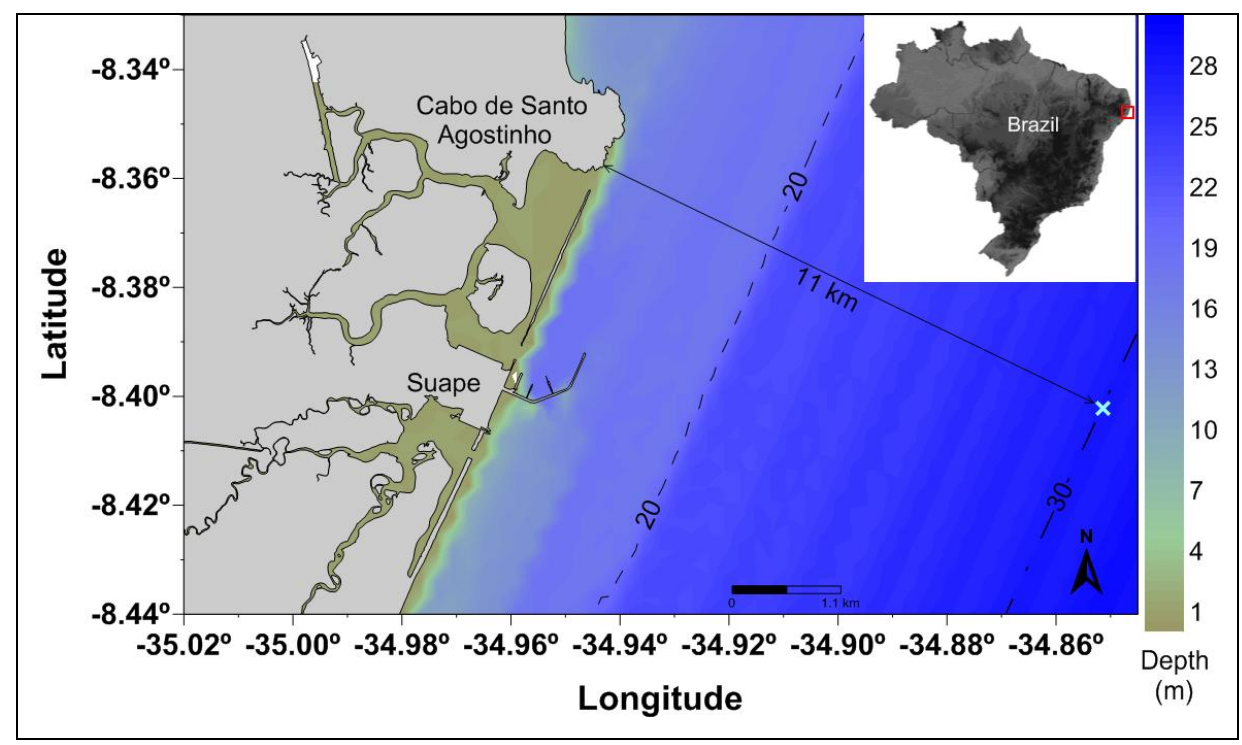

Figure 1 - Localization map in the coastal region of the Suape Harbor, Pernambuco, Brazil, presenting the experimental station $(\times)$, located $11 \mathrm{~km}$ away from the coastline (solid line). Isobaths of $20 \mathrm{~m}$ (dashed line) and $30 \mathrm{~m}$ (dashdotted line) are also plotted (SILVA, 2004).

The campaigns (referred to as $\mathrm{C} 1, \mathrm{C} 2, \mathrm{C} 3$ and $\mathrm{C} 4$ - see Tab. 1) were planned with the intent to: (i) characterize the evolution of hydrocarbons plumes in the water column during distinct seasonal and dynamic situations; and (ii) determine the existence of hydrodynamic forcing during the dry and rainy seasons for the neap and spring tides.

Table 1 - Summary of the sea campaigns.

\begin{tabular}{c|c|c|c}
\hline Period & Campaign & Tidal forcing & Date \\
\cline { 2 - 4 } Summer & C1 & Neap & $12 / 17-18 / 2007$ \\
\cline { 2 - 4 } & C2 & Spring & $12 / 23-24 / 2007$ \\
\cline { 2 - 4 } \multirow{2}{*}{ Winter } & C3 & Spring & $07 / 05-06 / 2008$ \\
\cline { 2 - 4 } & C4 & Neap & $07 / 10-11 / 2008$ \\
\hline
\end{tabular}

The field work was executed during neap and spring tides for each period of summer/dry (December 2007) and winter/rainy and (July 2008) to represent the primary seasons of the region (ARAGÃO, 2004). It was completed during tidal stages that characterized the extremes of the dynamic situation - slack water tidal period (high or low tidal stage) and dynamic tidal period (flood or ebb tidal stage).

This analysis is important due to the discrepancy between the seasonal periods concerning the physical characteristics of the area. The highest temperatures are observed from December to February (LINS, 2002), which correspond to the dry period, and consequently tides and evaporation increase the salinity at the surface. During the 
rainy period, heavy rains increase the continental runoff into the Suape Bay. Hence, the suspended particulate matter (i.e., the turbidity) increases and reduces the water transparency. The tides are additionally observed due to the influence of the gravitational forces. The spring tide represents the maximum tidal range, while the neap tide usually resembles tidal variations that are less than the mean tidal range.

Three vessels were simultaneously used to achieve all of the planned activities during each field campaign. Vessel V1 was responsible for the gas injection into the sea floor, the submarine video camera recordings and the diving staff. On board vessel V2, the data were collected for the thermohaline structures, and vessel V3 was used for the current meter settlement. A group of 12 scientists, operators and assistants participated in the field campaigns. Figure 2 shows the main activities during the subsurface blowout field experiment.

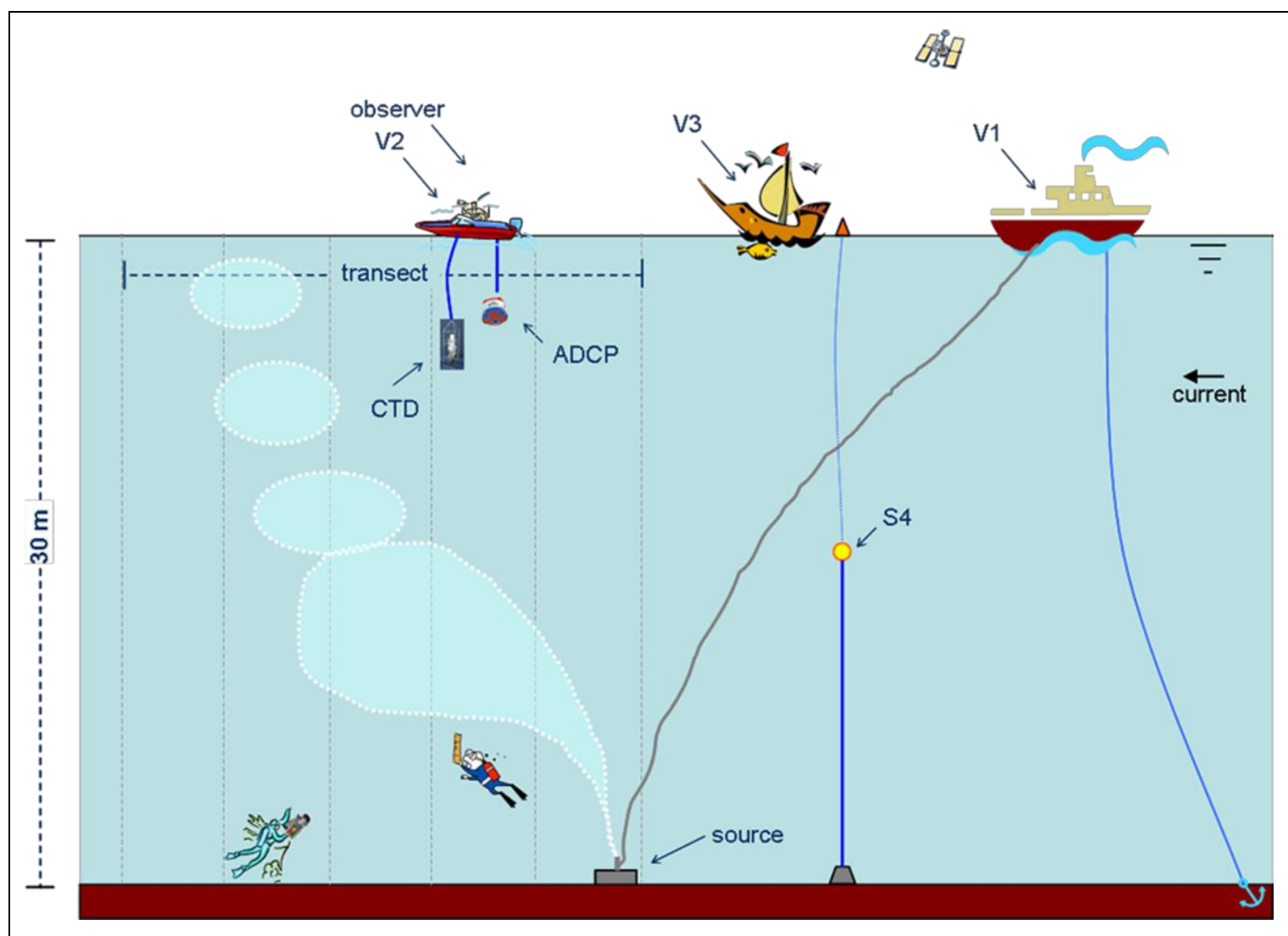

Figure 2 - Logistic scheme of the field campaigns.

\section{Release Arrangement}

Vehicular Natural Gas (VNG) was used because it is easy to acquire and to manipulate. The similarity between the composition of VNG and that of methane predominant gas from the exploitation reservoirs in the ocean was also important for this choice.

Three $7.5 \mathrm{~m}^{3}$ VNG cylinders (Fig. 3) were obtained for the gas injection into the water. The VNG was released from a device made especially for this purpose prior to the sea trial. This device was panel-like, with two simultaneous gas outlets, and consisted of two manometers and one rotameter. Each cylinder was connected to one manometer which was hooked to a rotameter linked to a hose. First, the pressure was defined and, subsequently, the gas flow was set to be released into the sea bottom. The outlet arrangement consisted of a U-shaped release pipe, which was moored to a $20 \mathrm{~kg}$ ballast, which directed the release almost vertically upwards. The diameter of the nozzle was $1 / 4$ of an inch, which was hooked to the ballast at $30 \mathrm{~m}$ depth. The gas was pumped down and transported as pressurized gas to the release platform through a $1 / 4$-inch flexible 
hose. The fluxes released (exit conditions) during the scenarios were set to 3,000 and 9,000 L.h $^{-1}$ (low and high flows, respectively), except for campaign C1, for which the low flow was set to 6,000 L.h. ${ }^{-1}$.

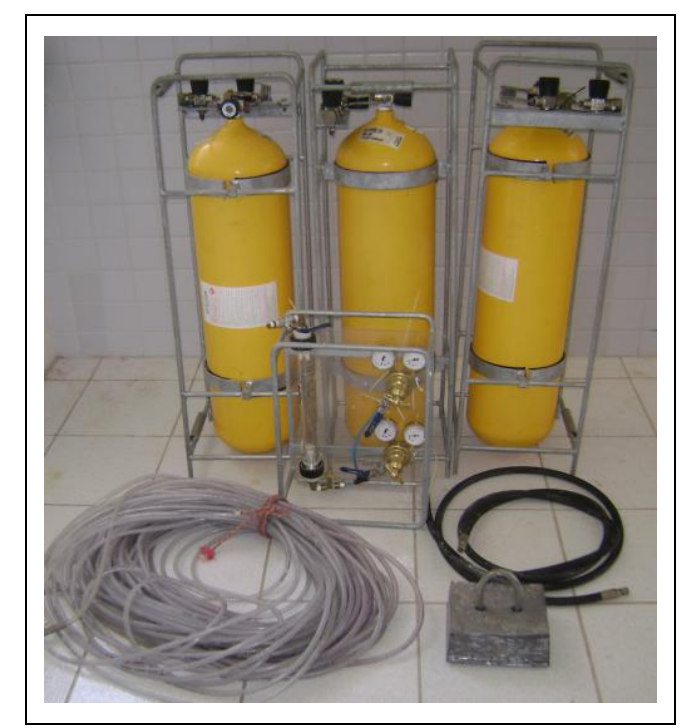

Figure 3 - Set of used equipment for gas release into the sea bottom.

\section{Video and Snapshot Camera Recordings}

The gas release from the bottom to the sea surface was recorded by a diver with a digital video camera (mod. Sony TRV130) in a waterproof case (mod. Croma-MR1). The camera had an "arm" attached in front of it with a depth gauge in its extremity. A second diver held a 1.4 meter ruler as a reference of size to later calculate the gas bubble plume dimension.

In order to obtain relevant plume data, flows from 3,000 to 9,000 L. $^{-1}$ of natural gas were released at approximately $30 \mathrm{~m}$ deep over a time span of approximately 15 minutes per release.

\section{Sea Measurements}

The plume direction and dispersion are directly affected by the tides; therefore the acquisition of current and wave data are important. Strong, cross-flowing currents tend to bend over the plume in the water column (YAPA et al., 2008), and waves lead to the dispersion of the plume close to the surface. Therefore, obtaining thermodynamic data are also necessary because they are involved in the rise velocity of the gas plume in addition to the gas physicochemical processes because of the density difference between gas and water.

Field measurements were carried out to collect background information, such as CTD, ADCP and S4 current meter data. The current intensity and direction were obtained with the ADCP equipment (mod. Workhorse Rio Grande $600 \mathrm{kHz}$ ), which was configured for 80 levels. Such levels correspond to the number of water profiling depth cells (WN) to cover the maximum expected water depth. Once the study area was defined to be around 30 meters depth, the $W N=80$ results on current measurements every $0.4 \mathrm{~m}$ along the water column. The ADCP was placed half a meter from the water surface, and two transects were taken at the gas plume area. One cross section surveyed along a zigzag course, and the other cross section surveyed in a straight line with the purpose of comprising the plume area.

Thermodynamic data from the area were acquired by the CTD equipment (mod. SBE-19plus Seacat Profiler). Generally, before the first gas flow release, two ADCP transects and one CTD profile were completed to be used as control data (with no gas release) for the hydrodynamic and thermodynamic surveys, respectively. Subsequently, one vertical CTD profile was obtained directly from the plume of rising droplets after two 
LEITE, F. S. et al. Field study of a simulated subsurface gas blowout in tropical and shallow water along the Brazilian Coast.

current meter transects during each gas flow release. Furthermore, the CTD data (salinity, temperature and density) were averaged in one-meter bins.

The wave field characterization and the tide gauge measurements were completed with the Interocean S4ADWi Current Meter. This equipment was moored for 24 hours at half the mean water depth. The current meter data were sampled at a rate of $2 \mathrm{~Hz}$ for periods of 30 minutes every three (two) hours in the summer (winter) period. The tide gauge data at $2 \mathrm{~Hz}$ frequency allowed for the characterization of the temporal evolution of low-frequency (tide-driven waves) and high-frequency waves (wind-driven waves) that occurred in the area during the campaigns. All of the field work was georeferenced using two Global Positioning System devices (GPSs; mod. Garmin III-Plus and mod. GPSmap Garmin 298 Sounder). The sea level variation was measured and compared to the tide forecast available from the Diretoria de Hidrografia e Navegação (Directorate of Hydrography and Navigation; DHN, 2007; 2008) of Brazilian Navy.

\section{RESULTS AND DISCUSSION}

Oceanographic data were obtained during the field campaigns with the purpose of enhancing the knowledge regarding gas blowouts in a prosperous gas/oil-producing tropical region.

\section{Wind Stress}

Wind forcing has been known to strongly influence gas transfer over the global ocean (WANNINKHOF et al., 2009) in addition to near-surface turbulence (ZAPPA et al., 2007). The wind fluctuation in the study area occurs on the scale of minutes, hours, days, weeks and months. Wind measurements obtained from the meteorological station of Porto de Galinhas ( $8.511^{\circ} \mathrm{S}, 35.003^{\circ} \mathrm{W}$ ) at $10 \mathrm{~m}$ height, which is located $15 \mathrm{~km}$ south of the study area, were used to define the wind effect during the field campaigns. Figure $4 a-b$ shows the seasonal-averaged wind data (2000 to 2005) at Porto de Galinhas, indicating that more intense and frequent winds come from southeast-east, with a mean intensity close to $7.0 \mathrm{~m} \cdot \mathrm{s}^{-1}$.

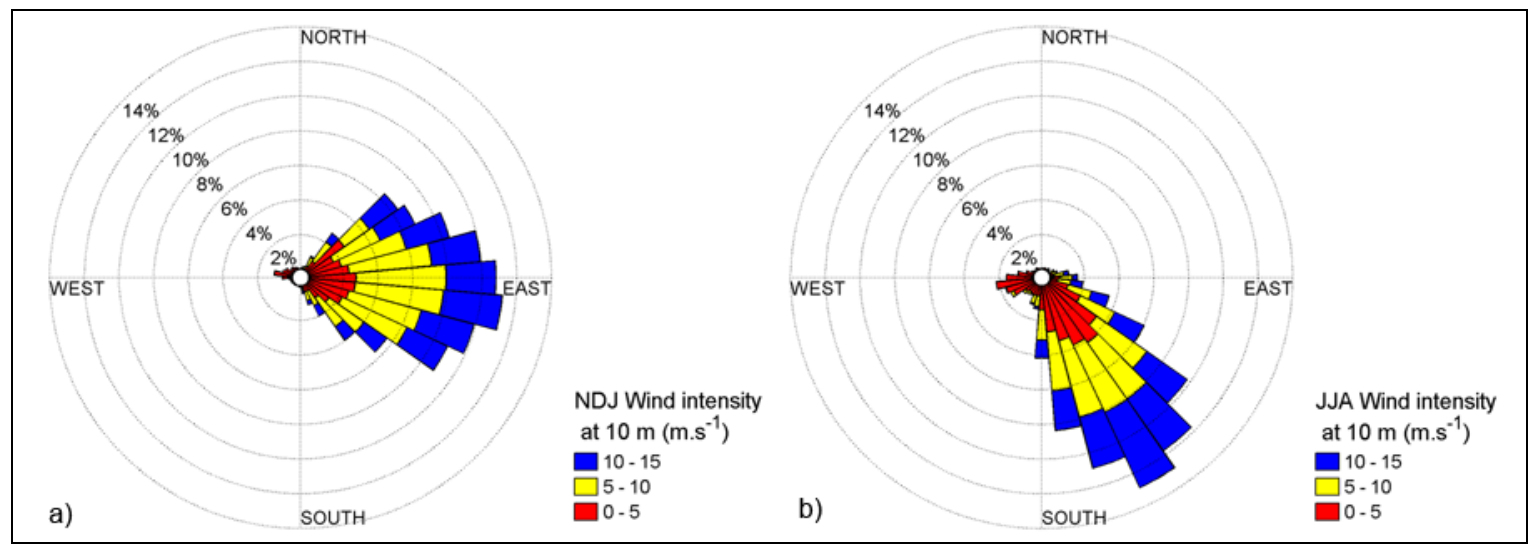

Figure 4 - Seasonal-averaged wind for: (a) summer period (NDJ means November to January); and (b) winter period (JJA means June to August) measured at 10 meters high in the Porto de Galinhas' meteorological station.

The mean direction is from the east-northeast from November to January (Fig. 4a), presenting mean intensity of $7.2 \mathrm{~m} . \mathrm{s}^{-1}$; and from the southeast during the period from June to August (Fig. 4b) with mean wind intensity of $6.6 \mathrm{~m} \cdot \mathrm{s}^{-1}$. Therefore, the prevailing winds change direction when they are influenced by an important meteorological system. As reported by Lins (2002), the southeasterlies prevail during the entire year, switching between east and northeast directions in summer periods.

According to Wunsch (2002) and numerous other studies, the upper layers of the ocean are driven by the wind and the top hundred meters of the mass flux is directly sustained by the wind stress. Considering the shallow depth of the field experiment, it is reasonable to expect this scenario to occur. However, because the site is near to the 
LEITE, F. S. et al. Field study of a simulated subsurface gas blowout in tropical and shallow water along the Brazilian Coast.

coast, the tide also has great control over the local dynamics. This tidal control possibility is also stated by Wunsch (2002), who observed that the mass flux of the ocean is controlled primarily by the wind and secondarily by the tidal forcing.

The wind effect over the natural gas amplifies its dissipation into the atmosphere.

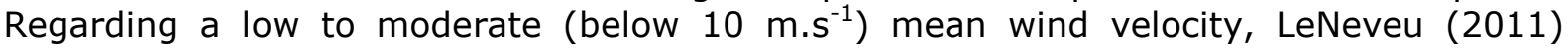
explained that, in general, the atmospheric concentrations of a gas are higher and less reliable at low wind speeds. This uncertainty can be dealt with probabilistic risk assessment.

\section{Wave Field}

The characteristics of high frequency surface waves result from the direct wind action and the interaction between the wave and the sea bottom, once these waves lead to the dispersion of the plume close to the surface. According to Wanninkhof et al. (2009), they have found a great intensification of gas fluxes caused by breaking waves and bubble entrainment. Additionally, Bock et al. (1999) found a reasonable correlation between the gas transfer velocity and short wind waves. However, despite the fact that the wave field strongly affects gas exchange, it is not yet possible to accurately quantify the effect of breaking waves on this exchange (WANNINKHOF et al., 2009).

With the primary purpose of observing the wave field, the S4ADWi current meter was deployed for $24 \mathrm{~h}$ on December $20^{\text {th }}, 2007$ (summer period campaigns) and July $5^{\text {th }}$, 2008 (winter period campaigns). Registered data from the S4ADWi were used to generate frequency diagrams of the significant wave height $\left(H_{s}\right)$, wave propagation direction $\left(\theta_{s}\right)$ and significant period $\left(T_{s}\right)$. Significant wave height is defined as the mean wave height of the highest third of the waves. $\theta_{s}$ is referenced by true north (zero degrees), increasing clockwise.

During the summer period, significant wave heights were registered between 0.7 to $1.0 \mathrm{~m}$, propagating in a bimodal direction of 210 and 320 degrees (mainly westward). These waves presented a significant period of 6.5 to 6.7 seconds. Waves with $\mathrm{H}_{\mathrm{s}}$ between 1.2 and $1.8 \mathrm{~m}$ were observed in this area during the winter period. These waves propagated mainly between 315 and 350 degrees (often northwestward) and presented a significant period of 7.0 to 7.4 seconds. These results are in agreement with the current observations that were performed by the ADCP equipment. They reveal the seasonal distribution of the prevailing winds at the Suape Harbor coastal region as previously described in the wind stress section.

\section{Current Measurements}

The current data obtained during the summer and winter periods are respectively shown in Figures 5 and 6 . It is expected that the cross-shore currents during dynamic tidal stages and the wind effects of different periods would influence the bending of the gas plume.

The data obtained during the field campaigns were submitted to a $95 \%$ confidence interval calculation, which aided in determining a statistically consistent representation of the field data. The results of this analysis are shown in the following sections.

\section{Summer period}

The summer season is represented by the first two field campaigns, which are described hereafter. According to the current data acquired during the neap ebb tide (Fig. $5 a)$, the current direction prevailed southward throughout the water column, with the exception of the bottom layer with no gas release (the control data), which presented a southwest direction. Slightly higher mean current intensities for this first field campaign were observed when the lowest $\left(6,000 \mathrm{~L} \cdot \mathrm{h}^{-1}\right.$ or $\left.0.1 \mathrm{~m}^{3} \cdot \mathrm{min}^{-1}\right)$ gas flow was released (maximum mean values at the surface of approximately $0.6 \mathrm{~m} . \mathrm{s}^{-1}$ ). Compared to the control data, the hydrodynamics did not show any highlighted differences in the current velocities and directions. This initial campaign had many mishaps, and because of that, it 
was not possible to obtain hydrodynamic and thermodynamic data from the slack water tidal period.

For the spring tide period, the current directions were predominantly southwestward. However, other current directions were also registered, excluding those northward and northeastward. The mean current intensities were stronger during the flood tidal stage, reaching up to $0.7 \mathrm{~m} . \mathrm{s}^{-1}$ at the surface during the high flow release $\left(9,000 \mathrm{~L} \cdot \mathrm{h}^{-1}\right.$ or $\left.0.15 \mathrm{~m}^{3} \cdot \mathrm{min}^{-1}\right)$.

During low tide (Fig. 5b), the three sets of current data (the control data and the low and high releases) presented different directions, which were southwestward, southward and southeast-eastward, respectively. The only altered behavior along the water column occurred at the bottom layer with no gas release, which showed a low mean northwestward intensity. The highest mean current intensity (approximately 0.5 m. $\mathrm{s}^{-1}$ ) was observed during the 9,000 L. $\mathrm{h}^{-1}$ flow release. The exception was at the bottom layer velocity, which was higher at the $3,000 \mathrm{~L}^{-1} \mathrm{~h}^{-1}\left(0.05 \mathrm{~m}^{3} \cdot \mathrm{min}^{-1}\right)$ release $\left(0.1 \mathrm{~m} \cdot \mathrm{s}^{-1}\right)$, followed by the highest flow.

At the moment of the flood tidal stage (Fig. 5c), the predominant direction was southwestward followed by the westward direction. The most intense currents were observed during the high flow release (approximately $0.7 \mathrm{~m} . \mathrm{s}^{-1}$ ), with the exception of the bottom layer. This layer later presented a high mean value of $0.2 \mathrm{~m} . \mathrm{s}^{-1}$ during the low flow $\left(3,000\right.$ L. $\left.\mathrm{h}^{-1}\right)$ release northwestward. 


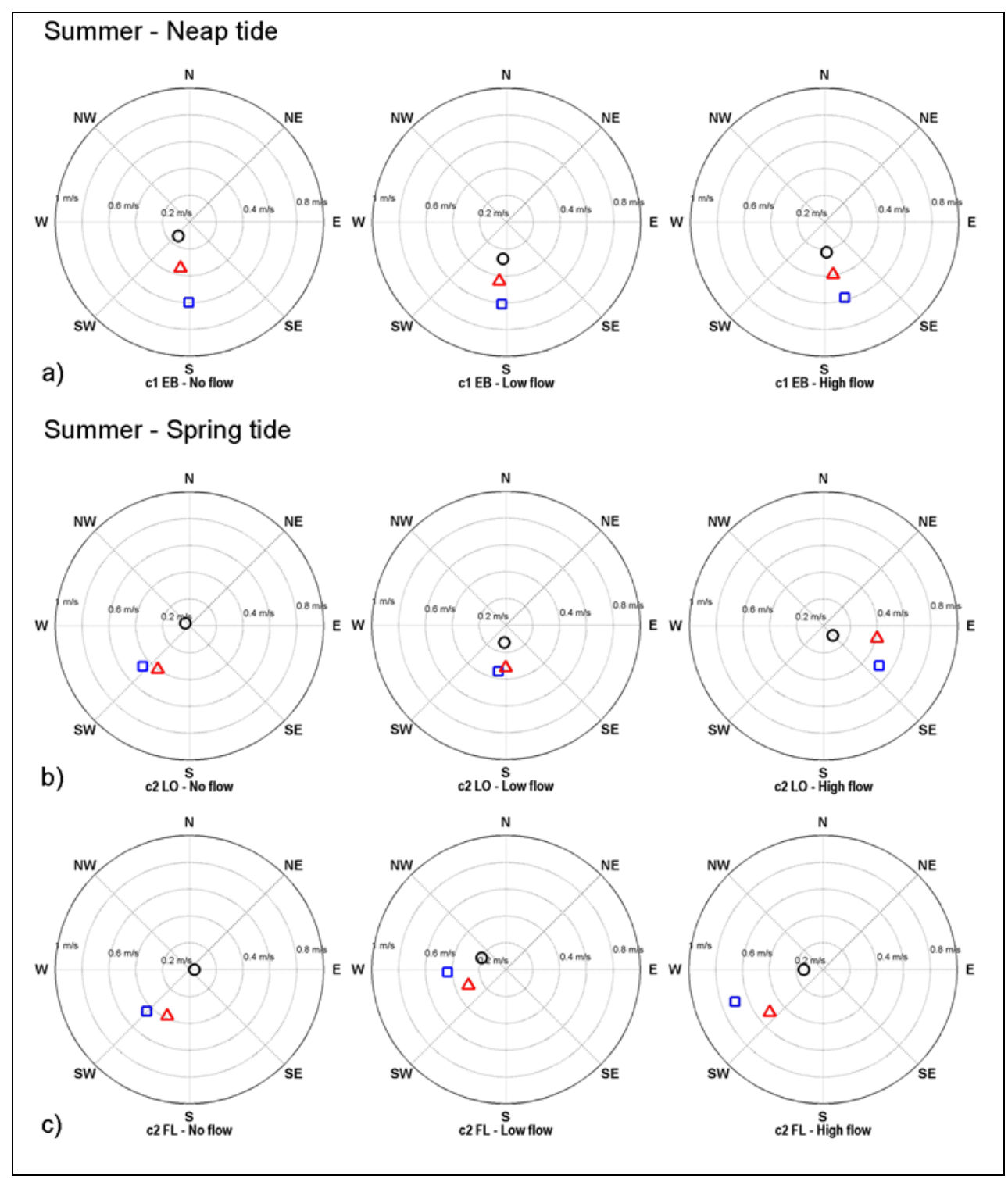

Figure 5 - Polar plots of the summer mean velocity current values for the surface $(\square)$, middle $(\triangle)$ and bottom (O) of the water column during (a) the neap ebb tide, (b) the spring low tide and (c) the spring flood tide.

\section{Winter period}

During the third campaign (Fig. 6a), data were only collected for the spring low tide due to rough sea conditions. The dominant current direction was northeastward. The highest mean surface intensity was registered during the 3,000 L.h ${ }^{-1}$ flow release (approximately $0.8 \mathrm{~m} . \mathrm{s}^{-1}$ ) while, for the other layers, more intense currents were observed during the control data acquisition. With no gas release, the current was at least $0.1 \mathrm{~m} . \mathrm{s}^{-1}$ different when compared to the data obtained during the gas releases and was predominantly directed northward.

For the neap tide data collection, the predominant current direction was northward, more specifically northeastward. The current intensities presented high mean surface values during the high flow release at the ebb tidal stage (approximately $0.5 \mathrm{~m} . \mathrm{s}^{-1}$ ). However, it was during the control data acquisition at high tide that the highest mean values were observed for the other two layers.

During high tide (Fig. 6b), the most frequent current direction was northwestward, except for the control data collection, which was directed northeastward. More intense currents were observed during the $9,000 \mathrm{~L} . \mathrm{h}^{-1}$ gas release (up to $0.4 \mathrm{~m} \cdot \mathrm{s}^{-1}$ ) at the 
LEITE, F. S. et al. Field study of a simulated subsurface gas blowout in tropical and shallow water along the Brazilian Coast.

surface. However, it was during the control data acquisition that more intense currents were registered for the other two water column layers.

By the time of the neap ebb tide (Fig. 6c), the current directions were more frequently toward the northeast-north, except for the bottom layer pointing eastward during the high flow. The highest mean intensities were registered during the high flow release (up to $0.5 \mathrm{~m} . \mathrm{s}^{-1}$ ), mainly for the surface and bottom layers. Without the gas release, currents directions prevailed to the north and the velocities were less intense than those observed during the gas releasing periods.

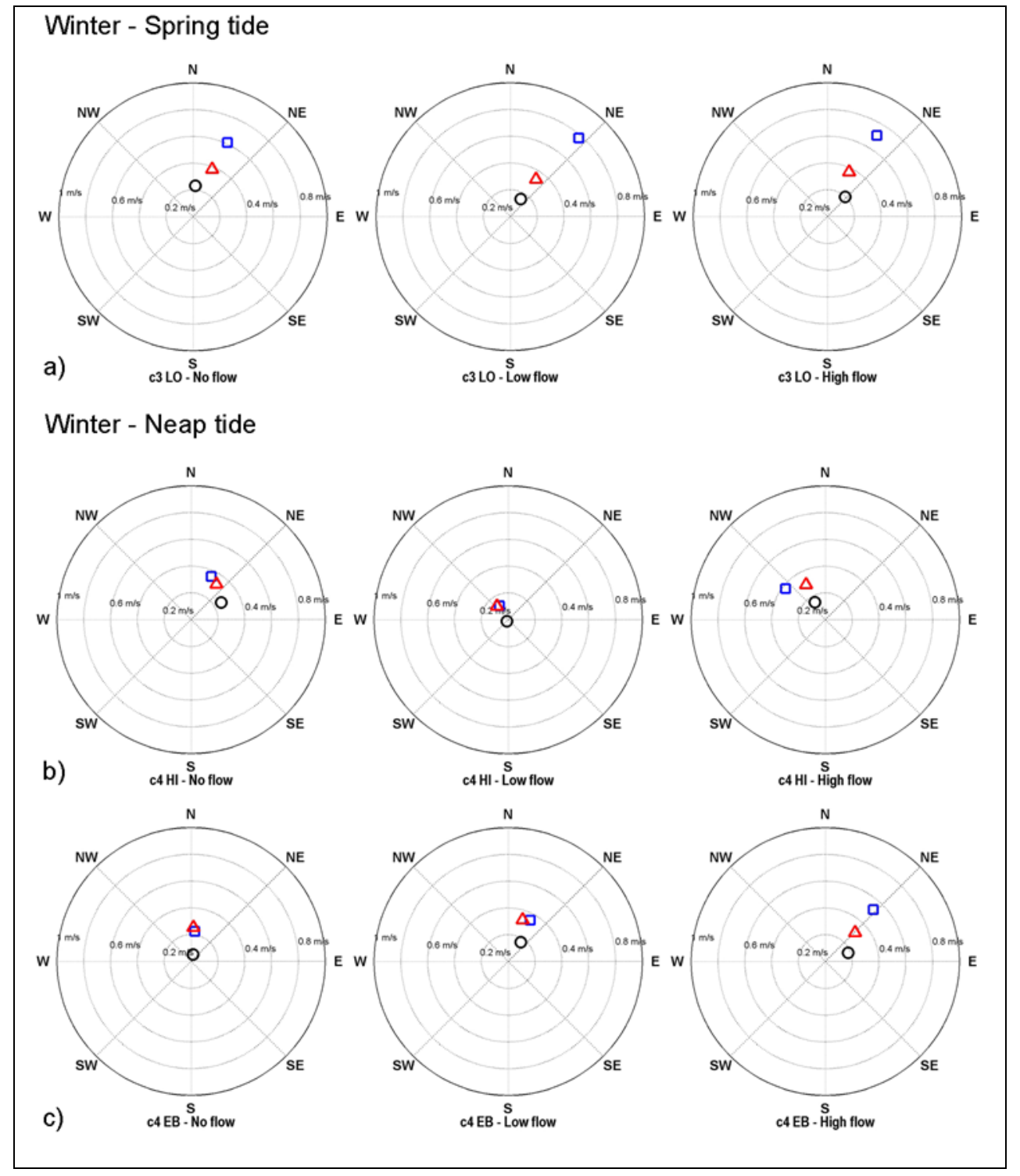

Figure 6 - Polar plots of the winter mean velocity current values for the surface $(\square)$, middle $(\triangle)$ and bottom (O) of the water column during (a) the spring low tide, (b) the neap high tide and (c) the neap ebb tide.

The current direction prevailed toward the south-southwest during the summer period, when northeasterly trade winds are present (ARAUJO et al., 2011). Otherwise, during the winter period, the northeastward current preponderated as a consequence of the southeasterly trades, which are common during this season (SILVA et al., 2009). Weak wind shear effects associated with strong bottom variations in current direction were observed during dynamic tidal stages, when gravitational forces overrule the flow, as was observed by Araujo et al. (2005). 
LEITE, F. S. et al. Field study of a simulated subsurface gas blowout in tropical and shallow water along the Brazilian Coast.

The third campaign registered the highest current intensities (up to $0.8 \mathrm{~m} . \mathrm{s}^{-1}$ at surface), which occurred in the spring low tide during the winter. This observation agrees with Araujo et al. (2005), who associated the stronger surface deviations in current intensity and direction to the slack water periods in Suape, when the wind shear stress is easily felt in the water column.

Current measurements were also registered by the S4ADWi current meter. A stick plot diagram, describing the current intensities and directions during the summer and winter campaigns, is presented in Figure 7. This figure also shows the comparison between the registered sea level variation and the variation forecasted by Suape Harbor (DHN, 2007, 2008).

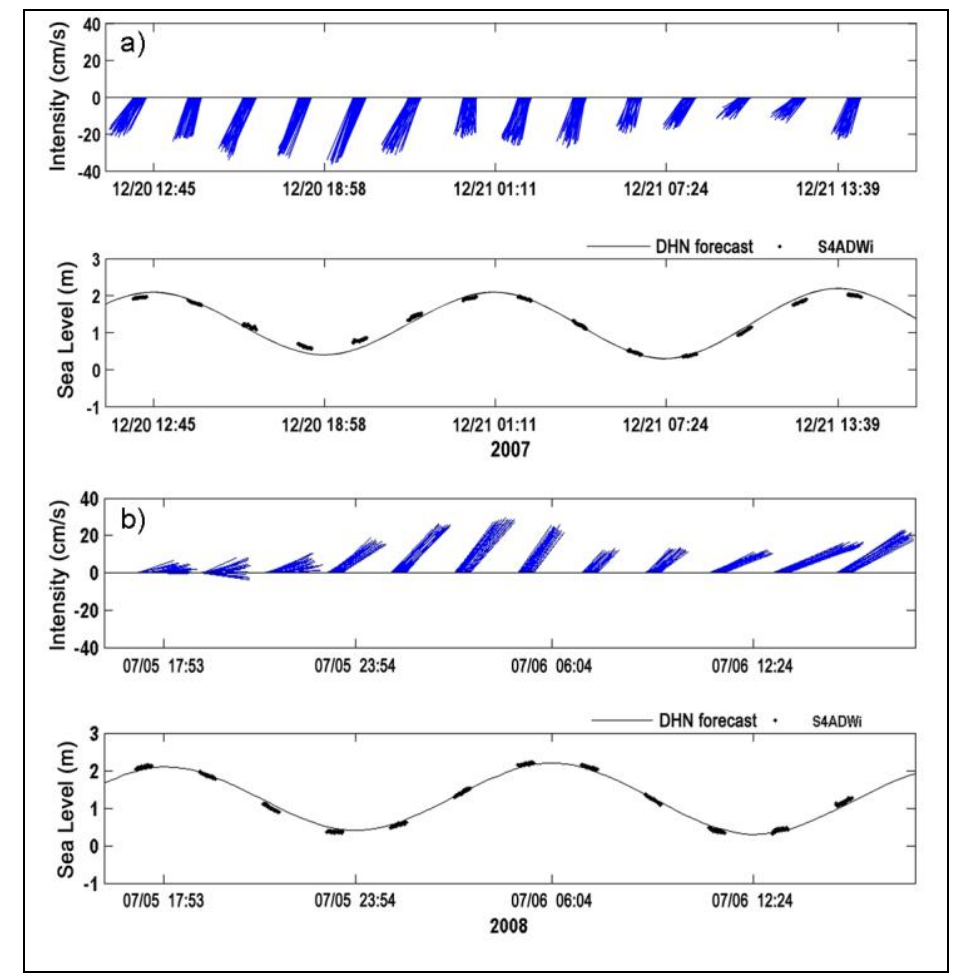

Figure 7 - Stick plot diagram of the current velocity vector and sea level variation registered at (a) the summer and (b) the winter period campaigns.

In the summer period, this equipment registered current intensities of up to 0.4 $\mathrm{m} . \mathrm{s}^{-1}$ and a predominant southwest-southward direction. The same intensity was also observed during the winter period; however, the current velocity mean value was higher during the winter and the northeastward current direction prevailed. The values that were obtained by the S4ADWi current meter were lower than those found by the ADCP. However, stronger currents were registered during the winter period by this profiler, as it was also detected by the S4ADWi current meter. Additionally, the directions of the currents were in complete agreement between both pieces of equipment, with the currents prevailing toward the southwest-south directions in the summer and northeastward in the winter period.

The incongruity in the current intensity results can be explained by the different dates that the S4ADWi current meter data were recorded (only $24 \mathrm{~h}$ for each period), when the tide, wind and other natural events (such as summer rains, droughts and extreme heat) are considered together. The agreement in current direction can be interpreted as the steady influence of the wind, which is more stable when considering the predominance during both periods.

Compared to the oscillations obtained by Suape Harbor (PE), the sea level variation in the study area during the dry and rainy periods was not significantly different from the 
LEITE, F. S. et al. Field study of a simulated subsurface gas blowout in tropical and shallow water along the Brazilian Coast.

calculated approximation given by DHN $(2007 ; 2008)$. Therefore, there was no important time lag between the measured values and those calculated at that harbor.

\section{Thermohaline Structure}

The thermodynamic data are presented in Figures 8 and 9, during the summer and winter periods, respectively. These data emphasize the physical differences between seasons, when salinity and temperature variations compromise the buoyancy and the rising velocity of the gas plume.

\section{Summer period}

The first field campaign, which occurred during the neap ebb tide with the release of 6,000 L. h $^{-1}$ flow, presented values of seawater physical properties (Fig. 8a) ranging between 37.0 and 37.2 for salinity, $25.8^{\circ} \mathrm{C}$ and $27.6^{\circ} \mathrm{C}$ for temperature and 1024.1 $\mathrm{kg} \cdot \mathrm{m}^{-3}$ and $1024.9 \mathrm{~kg} \cdot \mathrm{m}^{-3}$ for density. With the flow release of 9,000 L.h ${ }^{-1}$, the CTD values (Fig. 8b) varied from 36.9 to 37.2 for salinity, $25.8{ }^{\circ} \mathrm{C}$ to $27.6^{\circ} \mathrm{C}$ for temperature and a density range identical to the lowest flow release. The control data presented nearly the same behavior as the data when the gas flows were released. The salinity and density increased with depth, while the temperature presented the opposite behavior. Below 18 meters deep, the change in these parameters was negligible.

During the second campaign, at the spring low tide, the vertical distribution of the salinity/ temperature/ density (Fig. 8c) presented, respectively, minimum values of 36.9/ $25.3^{\circ} \mathrm{C} / 1024.1 \mathrm{~kg} \cdot \mathrm{m}^{-3}$ with a 3,000 L.h ${ }^{-1}$ gas flow release. The maximum values for these parameters were, respectively, $37.2 / 27.4 \mathrm{o} / \mathrm{C} / 1025.1 \mathrm{~kg} . \mathrm{m}^{-3}$. At close to 20 meters deep the thermocline ended, where the values of the parameters did not present any abrupt difference with increasing depth. The control data obtained during this tide were similar to the low flow release as shown in Figure $8 \mathrm{~d}$. Registers of these parameters during the 9,000 L.h ${ }^{-1}$ of natural gas release were the same as those for the low flow, except the maximum values of temperature and salinity, which presented only 0.1 unit of difference between the flows. At approximately 21 meters deep, which was the end of the thermocline, these values stabilized with depth.

At the spring flood tide, when a 3,000 L.h ${ }^{-1}$ gas flow was released, the vertical distribution of salinity, temperature and density (Fig. 8e) presented, respectively, minimum values of $36.8 / 25.3{ }^{\circ} \mathrm{C} / 1024.0 \mathrm{~kg} \cdot \mathrm{m}^{-3}$ and maximum values of $37.3 / 27.5^{\circ} \mathrm{C} /$ $1025.1 \mathrm{~kg} \cdot \mathrm{m}^{-3}$. During a 9,000 L.h ${ }^{-1}$ gas discharge (Fig. 8f), these parameters were identical to those from the low flow, except for the minimum salinity, which was only 0.1 higher. The base of these clines (for salinity, temperature and density) was close to a depth of 23 meters. These parameters became constant according to the increasing depth for both of the released flows. Similar to the first campaign, there was no explicit difference between these parameters for the different gas flow releases or the control data of this period. 


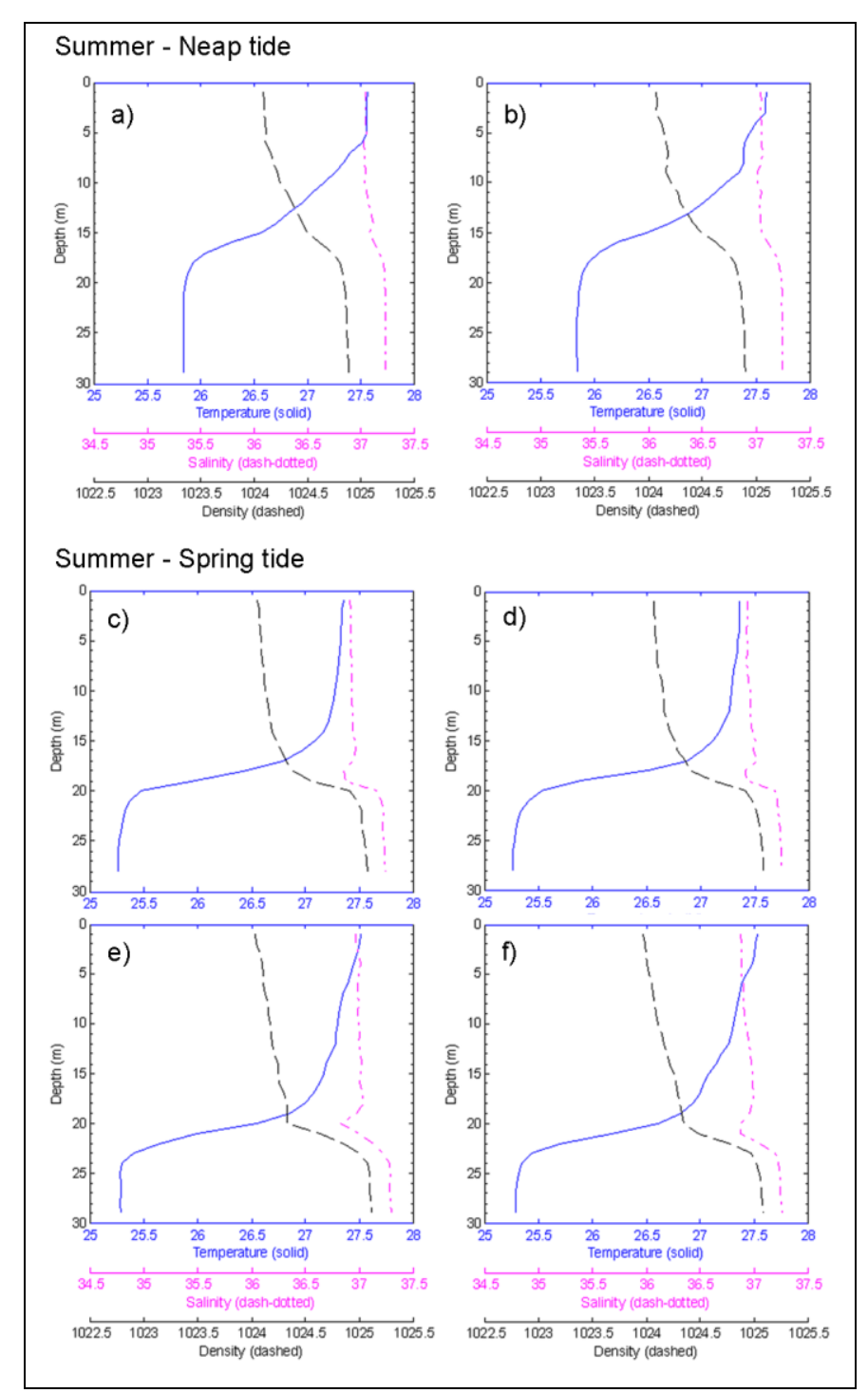

Figure 8 - Vertical CTD profiles during the summer period at neap ebb tide for flow releases of: (a) 6,000 L.h $\mathrm{h}^{-1}$ and (b) 9,000 L.h. ${ }^{-1}$. At spring low tide, for flow releases of: (c) 3,000 L.h. ${ }^{-1}$ and (d) no flow. At spring flood tide, for flow releases of: (e) 3,000 L.h ${ }^{-1}$ and (f) 9,000 L.h. ${ }^{-1}$.

\section{Winter period}

The third campaign corresponds to the spring low tide, when the thermodynamic data were not collected due to the sea condition during the first release of natural gas $\left(3,000\right.$ L.h $\left.{ }^{-1}\right)$. With the release of 9,000 L.h ${ }^{-1}$ of VNG, the salinity, temperature and density parameters (Fig. 9a) ranged between 34.7 and $37.0,26.0{ }^{\circ} \mathrm{C}$ and $26.3^{\circ} \mathrm{C}$ and $1022.8 \mathrm{~kg} \cdot \mathrm{m}^{-3}$ and $1024.5 \mathrm{~kg} \cdot \mathrm{m}^{-3}$, respectively. As shown in Figure 9b, the data obtained without gas release presented values identical to the flow release. Initially, these parameters increased with depth in both situations, but they became essentially constant after approximately 6 meters, which was at the base of the clines.

The last campaign, which occurred during the neap tide, began with the release of 3,000 L. h $^{-1}$ of gas at the high tide (Fig. 9c) and showed a vertical distribution of salinity/ temperature/ density, respectively, from 36.7 to $37.0,26 .{ }^{\circ} \mathrm{C}$ to $26.3^{\circ} \mathrm{C}$ and 1024.3 $\mathrm{kg} \cdot \mathrm{m}^{-3}$ to $1024.6 \mathrm{~kg} \cdot \mathrm{m}^{-3}$. Unlike the other scenarios, these values remained constant close to the surface. From approximately 9 meters and deeper, the salinity and density slightly increased with increasing depth, while the temperature values slowly decreased below this depth. The CTD values for the 9,000 L. $\mathrm{h}^{-1}$ flow release (Fig. 9d) comprised exactly the same ranges for salinity, temperature and density. Similar to the former flow 
LEITE, F. S. et al. Field study of a simulated subsurface gas blowout in tropical and shallow water along the Brazilian Coast.

release, these parameters were essentially constant near the surface, presenting lower values at approximately 8 meters deep. The salinity and density continued to increase toward the bottom, although the temperature became almost constant (with a slight decrease) starting from $14 \mathrm{~m}$ down to the bottom.

During the neap ebb tide, the vertical distribution of the seawater physical properties registered the same data range for the flow releases and control data (Fig. 9ef). The salinity values presented a range from 36.7 to 36.9 , while temperatures extended shortly from 26.2 to $26.4{ }^{\circ} \mathrm{C}$, and density presented limits from 1024.2 to $1024.5 \mathrm{~kg} . \mathrm{m}^{-3}$. The standard behavior of these parameters remained the same with increasing depth. However, the vertical distribution for both of the situations was slightly different. For the gas releases, the salinity and density began to rise constantly below $16 \mathrm{~m}$, while such an increase occurred below $14 \mathrm{~m}$ in the no-gas release scenario. The temperature decreased below the cited depths.

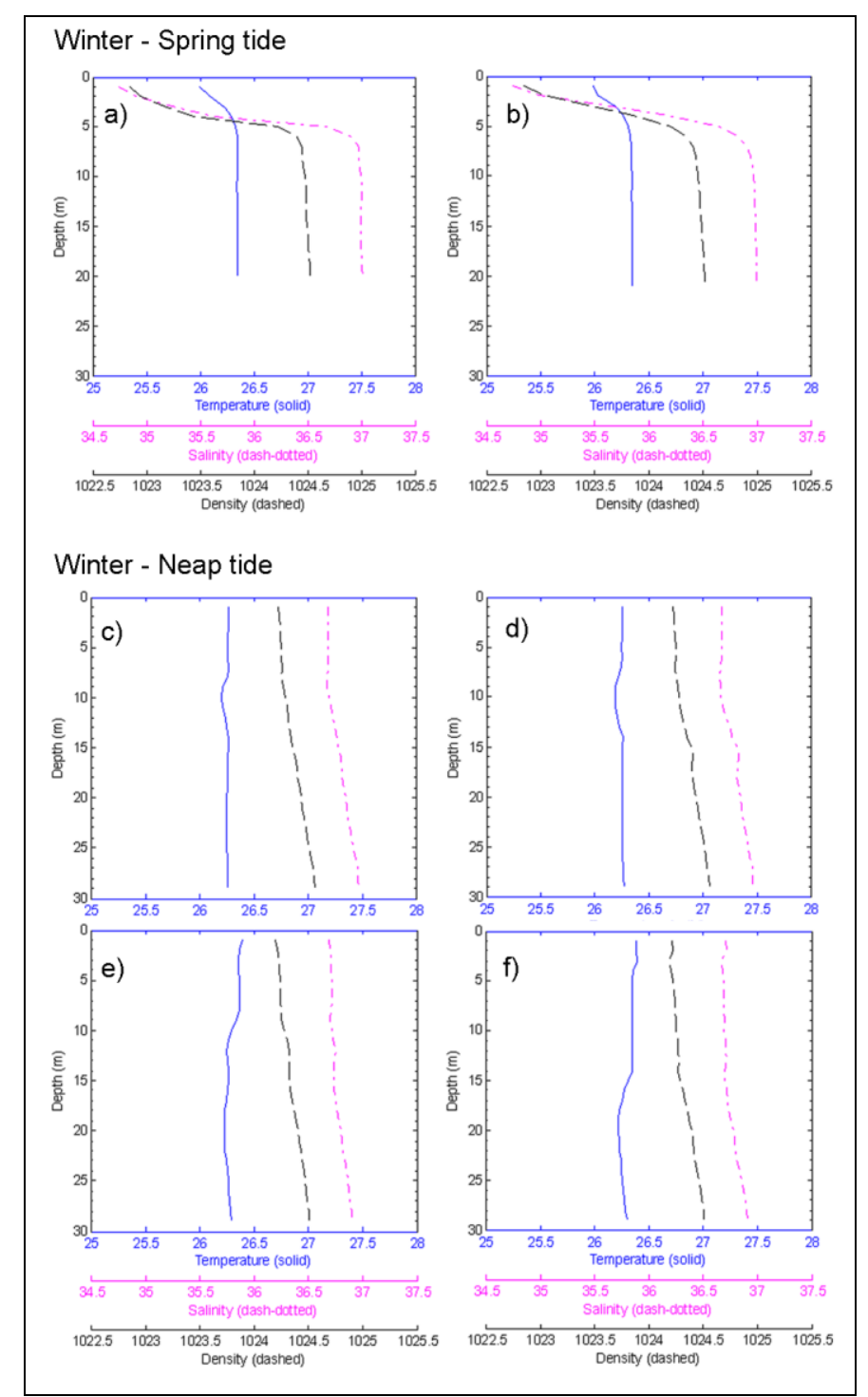

Figure 9 - Vertical CTD profiles during the winter period at spring low tide for flow releases of: (a) 9,000 L.h $\mathrm{h}^{-1}$ and (b) no flow. At neap high tide, for flow releases of: (c) 3,000 L.h.' ${ }^{-1}$ and (d) 9,000 L.h. ${ }^{-1}$. At neap ebb tide, for flow releases of: (e) 3,000 L.h. ${ }^{-1}$ and (f) no flow.

The highest temperature, density and salinity values were recorded during the summer period, primarily during the neap ebb tide, likely because of evaporation that overcomes precipitation, resulting in shallow saltier waters (LINS, 2002). At this tidal 
LEITE, F. S. et al. Field study of a simulated subsurface gas blowout in tropical and shallow water along the Brazilian Coast.

condition, the vertical temperature profile reveals a mixed layer extending to 7 meters deep, as well as the base of the thermocline near the depth of $18 \mathrm{~m}$. Additionally, a pycnocline and a halocline-like structure were observed in an interval between $5-18 \mathrm{~m}$. The maximum peak of temperature $\left(27.6^{\circ} \mathrm{C}\right)$ of all the four campaigns was registered during the high flow release of the neap ebb tide.

During the summer spring low tide, the lowest temperature of both periods was observed. Moreover, the gaps observed at the spring flood tide suggested the same approach reported by Rye et al. (1997). In experiments performed in stratified waters, McDougall (1978) and Asaeda and Imberger (1993) observed an undulating behavior of the plume in the vertical direction caused by stratification.

The greatest salinity and density differences along seawater depth (2.3 and 1.7 $\mathrm{kg} \cdot \mathrm{m}^{-3}$, respectively) were observed in the winter period, especially during the spring low tide. In general, the salinity and density data collected during this campaign contained the lowest values of all the campaigns. During this third campaign, there was a great inclination of the halocline and pycnocline from the surface down to 6 meters deep. The thermocline followed the same depth; however, temperature followed along a smoother variation, not exceeding $0.4^{\circ} \mathrm{C}$ of difference.

Areas with considerable variation within short depths are notable during the summer period due to the elevated values of temperature and salinity caused by solar radiation and evaporation, respectively, at the surface. As reported by Araujo et al. (2005), the water is homogeneous and well-mixed below this area, which is a common situation observed in coastal systems in the Northeast of Brazil (ARAUJO et al., 1999). In contrast, these variations along sea depth are not entirely clear in the winter season. This situation is likely caused by the intense southeasterly trade winds that are common during this period (ARAUJO et al., 2011) and can completely mix the shallow water column. However, a slight tendency toward increasing (decreasing) salinity and density (temperature) values occur with increasing depth.

\section{Subsurface Gas Releases and Recordings}

Johansen et al. (2003) suggested safety restrictions of surface vessel activities until all of the gas dissolves well beneath the surface in deep water blowouts. Blowouts in shallow waters are indeed dangerous once the gas reaches the surface, as has been observed during field campaigns, and can harm anyone who is on the surface using an engine.

The submarine recordings during all of the campaigns were performed outside the plume, which allowed for the observation of gas bubble clouds during the releases. It was possible to observe the displacement of the gas plume from the release point to the water surface. All of the observations and measurements of the plume width were recorded by the diver and confirmed in laboratory after screenshots and image analysis.

Examples of screenshots of the submarine recordings during summer and winter are presented in Figure 10. This set was chosen based on good screen visualization of the plume and the availability of simultaneous oceanographic data.

For the first campaign (C1), during summer, screenshots were obtained for the 9,000 L. $\mathrm{h}^{-1}$ flow release in the neap ebb tide. The width of the gas plume was one order of magnitude higher in the upper half of the water column than the lower half. Close to the bottom (approximately $24 \mathrm{~m}$ ), the plume diameter was approximately $0.3 \mathrm{~m}$, while near the surface (approximately $4 \mathrm{~m}$ deep), it was slightly higher than $2.0 \mathrm{~m}$. 
LEITE, F. S. et al. Field study of a simulated subsurface gas blowout in tropical and shallow water along the Brazilian Coast.

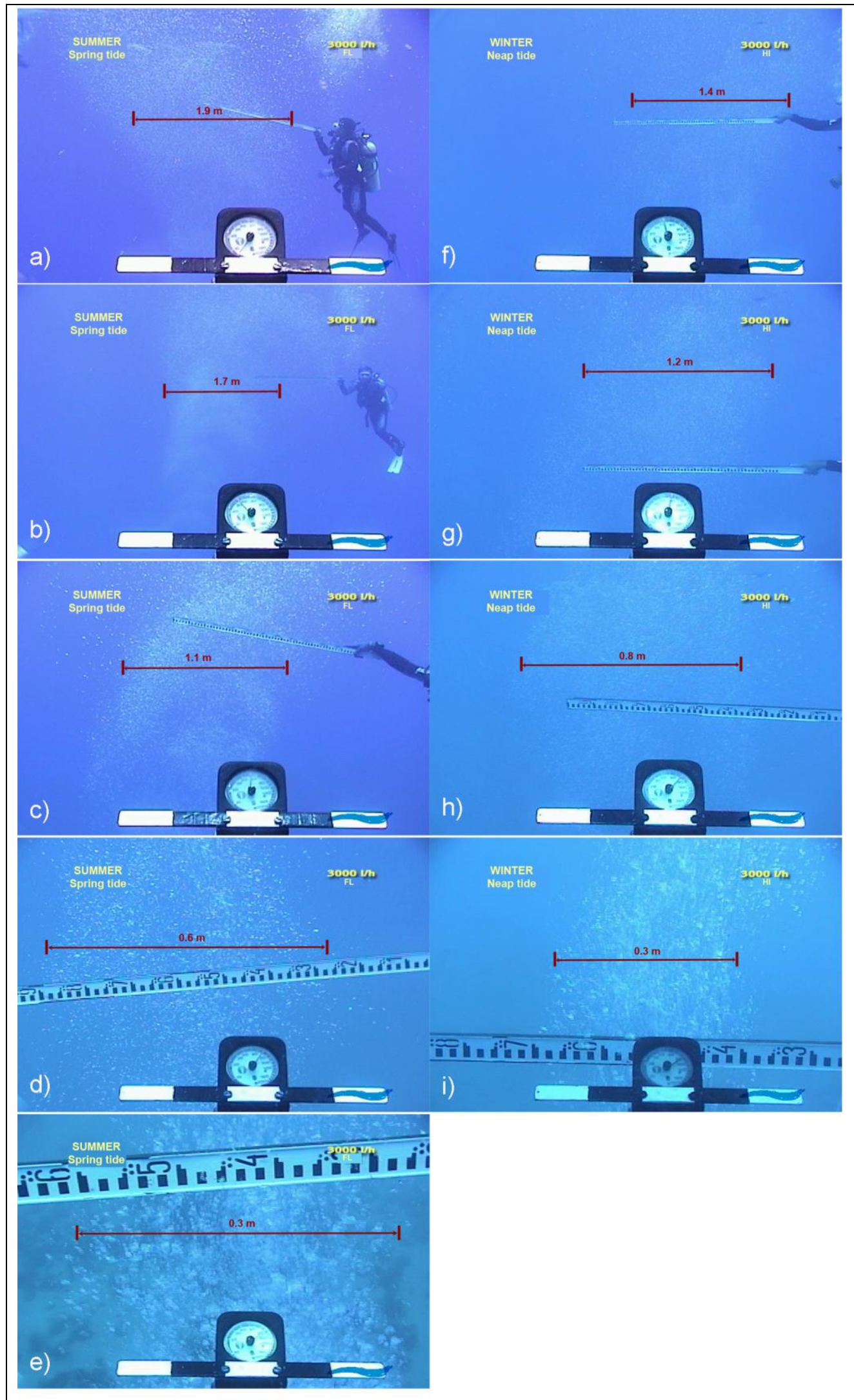

Figure 10 - Screenshots of the vertical evolution of the natural gas plume for the 3,000 L. $\mathrm{h}^{-1}$ flow release during the summer spring flood tide of $\mathrm{C} 2$ at depths of: (a) $2 \mathrm{~m}$, (b) $11 \mathrm{~m}$, (c) $15 \mathrm{~m}$, (d) $21 \mathrm{~m}$ and (e) $24 \mathrm{~m}$; for the 3,000 L. $\mathrm{h}^{-1}$ flow release during the winter neap high tide of $\mathrm{C} 4$ at depths of: (f) $13 \mathrm{~m}$, (g) $15 \mathrm{~m}$, (h) $21 \mathrm{~m}$ and (i) $24 \mathrm{~m}$ in the water column. 
LEITE, F. S. et al. Field study of a simulated subsurface gas blowout in tropical and shallow water along the Brazilian Coast.

In the second campaign ( $\mathrm{C} 2$ ), which occurred during the summer spring tide, the plume breadth for the low gas release at low tide was approximately $0.3 \mathrm{~m}$ at $24 \mathrm{~m}$ deep and reached $1.2 \mathrm{~m}$ at the surface. For the $9,000 \mathrm{~L} \cdot \mathrm{h}^{-1}$ flow release, the gas plume presented a diameter between $0.3 \mathrm{~m}$ close to the bottom (approximately $24 \mathrm{~m}$ ) and 2.7 $\mathrm{m}$ close to the surface (approximately $4 \mathrm{~m}$ depth). The images obtained during the flood tide of the C2 campaign presented plume diameters ranging from $0.3 \mathrm{~m}$ for both flow releases to $2.2 \mathrm{~m}$ for the $9,000 \mathrm{~L}^{-\mathrm{h}^{-1}}$ flow release $\left(0.3 \mathrm{~m}\right.$ above the 3,000 L. $\mathrm{h}^{-1}$ flow release - Fig. 10a-e). Despite the difference between the surface breadth of the low and high flow releases during the low tide, the order of magnitude of both tidal stages was the same for the C1 campaign.

The video recordings during the winter period presented muddy waters that brought difficulties in analyzing the gas plumes due to the poor visibility, mainly during the C3 spring tide. The visibility problem occurred because of a group of factors associated with moderate rainfall precipitation, strong surface wind stress, shallow depth, and estuarine output, such as levels of sediments, nutrient, pollutant and fresh water discharges into the ocean. For the neap tide, the last campaign (C4), the diameter of the plume was similar up to $15 \mathrm{~m}$ depth during both gas releases in the high tide. The diameter varied from $0.3 \mathrm{~m}$ close to the bottom to $1.2 \mathrm{~m}$ at the middle depth. However, the diameter near depths of $13 \mathrm{~m}$ was approximately $1.4 \mathrm{~m}$ during the low flow release (Fig. 10f-i), while it was approximately $1.3 \mathrm{~m}$ at $6 \mathrm{~m}$ from the surface for the 9,000 L.h $\mathrm{h}^{-1}$ flow release. One can presume with these measurements that the plume diameter during the low flow release must be wider and closer to the surface. It was not possible to measure the plume diameter in the video recordings due to the camera approach. However, the video approach reaffirms the presumption of a bigger plume diameter.

According to the data, the gas plume displaced southward during the first campaign. During the second campaign, the plume presented a similar area at the surface during the highest gas flow release at both tidal stages. However, in contrast to campaign $\mathrm{C} 1$, the plume moved southwestward, which was closer to the coast, during the flood tide.

The width of the plume was similar from the bottom to the middle depth of the water column for all of the campaigns, which some images were able to capture. The difference appeared mainly at the surface, where the wind, wave, current and thermohaline structure may act all together to give a particular characteristic to the plume behavior. Observations from the vessel during the gas releases showed that the plumes took approximately 1.5 minutes to reach the sea surface. Yet, during all of the experiments, the gas rapidly dispersed upward when it reached the sea surface. The dispersion occurred due to the fact that natural gas is $35 \%$ lighter than air (RIVKIN, 2007; OBANIJESU and MACAULAY, 2009) and, in a shallow area, it passes throughout the water column.

During the summer period, the gas plume presented a width higher than $2 \mathrm{~m}$ close to the surface and a displacement southward at the first campaign, which is explained mainly by tidal forcing. The video images generally indicated southward current directions with mean surface intensities of $0.6 \mathrm{~m} . \mathrm{s}^{-1}$, which induced the plume transport towards this direction. The significant wave height presented lower values (from 0.7 to $1.0 \mathrm{~m}$ ) compared to the winter values, and the wave direction prevailed westward, with a significant period of approximately 6.6 seconds.

The tendency of the plume to displace southwestward during the summer spring tide was observed in both tidal stages. The surface plume width at this condition varied from $1.2 \mathrm{~m}$ to $2.7 \mathrm{~m}$ at the surface. This behavior represents a mix of meteorological and tidal forcing influences. As presented by the wind results and observed by other authors (LINS, 2002; ARAUJO et al., 2011), the winds vary between the east and northeast during the summer, despite the southeasterly predominance in this region. Moreover, currents moved toward the southern and western directions with mean current velocities varying between 0.4 and $0.7 \mathrm{~m} . \mathrm{s}^{-1}$, which may influence the plume displacement. 
LEITE, F. S. et al. Field study of a simulated subsurface gas blowout in tropical and shallow water along the Brazilian Coast.

The winter period presented a mixed water column with stronger southeasterly trade winds, a higher significant wave height, which varied from 1.2 to $1.8 \mathrm{~m}\left(T_{\mathrm{s}} \sim 7.2\right.$ $\mathrm{s})$, and a wave direction towards the northwest-north. Higher intensity currents moving northeastward were observed mainly during the spring tide campaign. According to the data collected, the gas plume likely moved toward the northeast-north direction.

During the winter neap tide it was possible to obtain screenshots of the plume evolution in the water column. The inclination of the plume displacement was northeastward, because the wind and wave conditions were prominent. In addition to these conditions, the current direction also predominated northeastward, and its intensities reached $0.5 \mathrm{~m} . \mathrm{s}^{-1}$, which contributed to the narrower plume width.

Table 2 presents a synthesis of the results with the main characteristics of the gas plumes observed during the sea campaigns.

Table 2 - Synthesis of the observed results of the gas plumes during the sea campaigns.

\begin{tabular}{c|c|c|c}
\hline Period & Tide & Plume Transport & Mean Plume Width at Surface (m) \\
\hline \multirow{2}{*}{ Summer } & Neap & S & 2.0 \\
\cline { 2 - 4 } & Spring & SW & 2.7 \\
\hline \multirow{2}{*}{ Winter } & Neap & NE-N & 1.4 \\
\cline { 2 - 4 } & Spring & NE & 2.0 \\
\hline
\end{tabular}

\section{CONCLUSION}

As far as we know this study represents the first gas release experiment performed in shallow and tropical waters. Four distinct scenarios with different geophysical forcing were associated with two different gas release rates and seasonal periods. It was possible to collect a comprehensive and valuable data set to supply a baseline data for model calibration and validation in addition to documenting the methodology. The information allowed for the characterization of the plume evolution throughout the water column in distinct conditions of geophysical forcing associated with seasonal periods.

Results confirm that gas plume displacement was always influenced by the tidal and meteorological forcings. During the austral summer, the wind blew from the eastnortheast with mean intensity of $7.2 \mathrm{~m} . \mathrm{s}^{-1}$. Significant wave heights were registered around $0.9 \mathrm{~m}$ propagating mainly westward with significant period about $6.7 \mathrm{~s}$. Mean surface current intensities were around $0.5 \mathrm{~m} . \mathrm{s}^{-1}$ toward the south-southwest direction. Vertical stratification was clear at the water column with values of seawater physical variables almost constant below 20 meters deep. The gas plume displaced southsouthwestward and presented an observed plume width up to $2.7 \mathrm{~m}$ close to the surface. During the austral winter, the wind blew stronger from the southeast presenting mean intensity of $6.6 \mathrm{~m} . \mathrm{s}^{-1}$. Significant wave heights around $1.6 \mathrm{~m}$ were registered propagating often northwestward with significant period about 7.2 s. Mean surface current intensities were around $0.5 \mathrm{~m} . \mathrm{s}^{-1}$ toward the northeast direction. A slight mixed water column was observed. The gas plume presented a width higher than $1.3 \mathrm{~m}$ close to the surface and a northeast-northward displacement.

Because of the paucity of studies in tropical shallow waters, available information in literature concerning methodological approaches and field data collection has focused primarily on temperate deep waters. As this is the first known gas experiment performed in the shallow coastal waters of Brazil, it seems also important to register difficulties and suggestions for later studies. For example, a considerable improvement for this methodology would be setting four rectangular GPS waypoints, with the gas release location and the potential area for plume dispersion inside it to acquire better data for comparison. This simple practical approach would avoid additional efforts to align and to compare measurements issued from different campaigns.

Another aspect is associated with the absence of a real-time strict recording control from the surface, which would lead to a better capture of the overall plume evolution. Additionally, the water turbidity during winter campaigns lowered the quality of the video

Tropical Oceanography, Recife, v. 40, n. 2, p. 243-264, 2012 
LEITE, F. S. et al. Field study of a simulated subsurface gas blowout in tropical and shallow water along the Brazilian Coast.

recordings. Such mishaps could be amended with the use of a camcorder spotlight or, even better, with the use of a ROV. Finally, the ADCP results sometimes did not registered the data, which could be associated with the intersection of the transmitted pulse with the gas bubbles. As experienced by Johansen et al. (2003), the use of echo sounders was effective for tracking the gas bubbles as the bubbles raised through the water column. This observation points out a probable calibration problem for the ADCP use because it operated with a $600 \mathrm{kHz}$ transducer, while Johansen et al. (2003) tested transducers from 18 to $200 \mathrm{kHz}$, and the best results came from the $38 \mathrm{kHz}$ transducer. Several tests with the ADCP frequency should be taken into account. These experiments would help to calibrate the equipment and to obtain an accurate value to track gas bubbles. It has been fairly successful for former researchers in deeper waters in obtaining higher quality dimension measurements of the plume.

The earlier suggestions would lead to improve data quality for next in situ experiments. Nevertheless, results presented and discussed here represent an original and very useful dataset for calibration and validation of underwater gas blowout models in tropical and shallow oceanic systems.

\section{AKNOWLEDGEMENTS}

This research was financially supported by the Brazilian National Research Council (CNPq) under the project grants 550197/2005-2 (CTPetro 16/2005) and 558143/2009-1 (CTHidro/CTInfra 38/2009). The authors are thankful to everyone who was engaged in the field campaigns. The authors also thank Dr. Raul Montagne (UFRPE, Brazil) and Fabrice Hernandez (IRD, France) for providing valuable comments that improved the manuscript.

\section{REFERENCES}

ARAGÃO, J. O. R. A Influência dos Oceanos Pacífico e Atlântico na Dinâmica do Tempo e do Clima do Nordeste do Brasil. In: Eskinazi-Leça, E.; Neumann-Leitão, S.; Costa, M. F. (Orgs.). Oceanografia: Um cenário tropical. $1^{\text {a }}$ ed. Recife/PE: Edições Bagaço, 2004. p. 131-184.

ARAUJO, M.; LHERITIER, D.; SILVA, M. A.; LUNA, M. C.; MEDEIROS, C. Tidal turbulence and eddy-viscosity in coastal waters at northeastern Brazil. Journal of Coastal

Research, v. 21, p. 18-27, 2005.

ARAUJO, M.; LIMONGI, C.; SERVAIN, J.; SILVA, M.; LEITE, F. S.; VELEDA, D.; LENTINI, C. A. D. Salinity-induced mixed and barrier layers in the Southwestern tropical Atlantic Ocean off the Northeast of Brazil. Ocean Science, v. 7, p. 63-73, 2011.

ARAUJO, M.; MEDEIROS, C.; RIBEIRO, C. Energy balance and time-scales of mixing and stratification in the Jaboatão estuary, NE-Brazil. Revista Brasileira de Oceanografia, V. 47, p. 145-154, 1999.

ASAEDA, T.; IMBERGER, J. Structure of bubble plumes in linearly stratified environments. Journal of Fluid Mechanics, v. 249, p. 35-57, 1993.

BEEGLE-KRAUSE, C. J.; LYNCH, W. Combining modeling with response in potential deep well blowout: lessons learned from thunder horse. Proceedings of the International Oil Spill Conference, Miami Beach, p. 1-6, 2005.

BOCK, E. J.; HARA, T.; FREW, N. M.; MCGILLIS, W. R. Relationship between air-sea gas transfer and short wind waves. Journal of Geophysical Research, v. 104, p. 2582125831, 1999.

BREWER, P. G.; ORR JR., F. M.; FRIEDERICH, G.; KVENVOLDEN, K. A.; ORANGE, D. L.; MCFARLANE, J.; KIRKWOOD, W. Deep-ocean field test of methane hydrate formation from a remotely operated vehicle. Geology, v. 25, p. 407-410, 1997.

BREWER, P. G.; ORR JR., F. M.; FRIEDERICH, G.; KVENVOLDEN, K. A.; ORANGE, D. L. Gas hydrate formation in the deep sea: in situ experiments with controlled release of methane, natural gas, and carbon dioxide. Energy \& Fuels, v. 12, p. 183-188, 1998. 
LEITE, F. S. et al. Field study of a simulated subsurface gas blowout in tropical and shallow water along the Brazilian Coast.

BULATOV, M. G.; KRAVTSOV, Yu. A.; RAEV, M. D.; REPINA, I. A.; SKVORTSOV, E. I. Microwave, optical and IR combined studies of the sea surface perturbations caused by underwater gas bubble plumes. IEEE Geoscience and Remote Sensing Symposium. IGARSS 2002, v. 5, p. 2983-2985, 2002.

CHEN, F. H.; YAPA, P. D. A model for simulating deepwater oil and gas blowouts - Part II: comparison of numerical simulations with "DeepSpill" field experiments. Journal of Hydraulic Research, v. 41, n. 4, p. 353-365, 2002.

DHN - Diretoria de Hidrografia e Navegação, 2007. Tábuas das marés. WWW Page, http://www.dhn.mar.mil.br (accessed 12.05.2007).

DHN - Diretoria de Hidrografia e Navegação, 2008. Tábuas das marés. WWW Page, http://www.dhn.mar.mil.br (accessed 06.30.2008).

FISCHER, D. W. Managing technological accidents: two blowouts in the North Sea. IIASA Proceedings Series, Pergamon Press, Oxford, 234 p., 1982.

JOHANSEN, $\varnothing$. DeepBlow - a Lagrangian plume model for deep water blowouts. Spill Science \& Technology Bulletin, v. 6, p. 103-111, 2000.

JOHANSEN, Ø.; RYE, H.; MELBYE, A.; JENSEN, H.; SERIGSTAD, B.; KNUTSEN, T. Deep Spill JIP Experimental Discharges of Gas and Oil at Helland Hansen, Parts I, II, and III - Technical Report, SINTEF Applied Chemistry, Norway, 2001.

JOHANSEN, Ø.; RYE, H.; COOPER, C. DeepSpill - Field study of a simulated oil and gas blowout in deep water. Spill Science \& Technology Bulletin, v. 8, p. 433-443, 2003.

LENEVEU, D. M. Analysis of potential acid gas leakage from wellbores in Alberta, Canada. International Journal of Greenhouse Gas Control, v. 5, n. 4, p. 862-879, 2011.

LINS, P. A. M. Hidrologia e hidrodinâmica do baixo estuário do Rio Ipojuca, PE. MSc Thesis, Department of Oceanography, Federal University of Pernambuco, Brazil, 2002.

MCDOUGALL, T. J. Bubble plumes in stratified environments. Journal of Fluid Mechanics, v. 85, p. 655-672, 1978.

OBANIJESU, E. O.; MACAULAY, S. R. A. West African Gas Pipeline (WAGP) project: associated problems and possible remedies. In: YANFUL, E. K. (Ed.). Appropriate Technology for Environmental Protection in the Developing World. Springer Books: Netherlands, 2009. p. 101-112.

PEEL, M. C.; FINLAYSON, B. L.; MCMAHON, T. A. Updated world map of the KöppenGeiger climate classification. Hydrology and Earth System Sciences, v. 11, p. 16331644, 2007.

RIVKIN, P. E. Hazards and hazard mitigation techniques for natural gas and hydrogen fueling operations. Process Safety Progress, v. 26, p. 27-34, 2007.

RYE, H.; BRANDVIK, P. J.; STROM, T. Subsurface blowouts: results from field experiments. Spill Science \& Technology Bulletin, v. 4, p. 239-256, 1997.

SILVA, M. A. Modelagem matemática da circulação e da dispersão de poluentes na região costeira do Porto de Suape - PE, Brasil. MSc Thesis, Department of Oceanography, Federal University of Pernambuco, Brazil, 2004.

SILVA, M. A.; ARAUJO, M.; SERVAIN, J.; PEVEN, P.; LENTINI, C. A. D. High-Resolution Regional Ocean Dynamics Simulation in the Southwestern Tropical Atlantic. Ocean Modelling, 30, 256-269, 2009.

WANNINKHOF, R.; ASHER, W. E.; HO, D. T.; SWEENEY, C. S.; MCGILLIS, W. R. Advances in quantifying air-sea gas exchange and environmental forcing. Annual Review of Marine Science, v. 1, p. 213-244, 2009. 
LEITE, F. S. et al. Field study of a simulated subsurface gas blowout in tropical and shallow water along the Brazilian Coast.

WUNSCH, C. What is the thermohaline circulation? Science. V. 298, p. 1179-1180, 2002.

YAPA, P. D.; DASANAYAKA, L. K.; BANDARA, U. C.; NAKATA, K. Modeling the impact of an accidental release of methane gas in deepwater. In: OCEANS 2008, 15-18 Sept. 2008, Quebec, CA. Conference publication, p. 1-10, 2008.

YAPA, P. D.; ZHENG, L.; NAKATA, K. Modeling Underwater Oil/Gas Jets and Plumes. Journal of Hydraulic Engeneering, v. 125, n. 5, 16872, 1999.

ZAPPA, C. J.; MCGILLIS, W. R.; RAYMOND, P. A.; EDSON, J. B.; HINTSA, E. J.; ZEMMELINK, H. J.; DACEY, J. W. H.; HO, D. T. Environmental turbulent mixing controls on air-water gas exchange in marine and aquatic systems. Geophysical Research Letters, v. 34, L10601, doi:10.1029/2006GL028790, 2007.

ZHENG, L.; YAPA, P. D.; CHEN, F. H. A model for simulating deepwater oil and gas blowouts - Part I: theory and model formulation. Journal of Hydraulic Research, $v$. 41, n. 4, p. 339-351, 2002. 